\title{
KARAKTERISTIK BUDAYA SEKOLAH DI SMP NEGERI 15 YOGYAKARTA SEBAGAI PELAKSANA PROGRAM SEKOLAH RESPONSIF GENDER
}

\section{THE CHARATERISTIC OF THE SCHOOL CULTURE IN JUNIOR HIGH SCHOOL OF 15 YOGYAKARTA AS THE IMPLEMENTER OF GENDER RESPONSIVE SCHOOL PROGRAM}

\author{
Muhamad Hendra Prasetya \\ Filsafat dan Sosiologi Pendidikan, Kebijakan Pendidikan FIP UNY \\ muhamad.hendra2016@student.uny.ac.id
}

\begin{abstract}
Abstrak
Penelitian ini bertujuan untuk: 1) mendeskripsikan karakteristik budaya sekolah di SMP Negeri 15 Yogyakarta sebagai pelaksana program sekolah responsif gender; 2) mendeskripsikan faktor pendukung dan penghambat sekolah dalam pelaksanaan budaya sekolah responsif gender. Penelitian ini menggunakan pendekatan kualitatif metode deskriptif. Subjek dalam penelitian ini adalah kepala sekolah, guru, peserta didik dan orang tua peserta didik. Objek dalam penelitian ini adalah karakteristik budaya sekolah di SMP Negeri 15 Yogyakarta sebagai pelaksana program sekolah responsif gender. Setting penelitian ini di lakukan di SMP Negeri 15 Yogyakarta. Teknik pengumpulan data menggunakan observasi, wawancara dan dokumentasi. Teknik analisis data menggunakan model analisis data Miles dan Huberman. Adapun teknik keabsahan data menggunakan triangulasi sumber dan triangulasi teknik. Hasil penelitian ini menunjukkan bahwa: 1) karakteristik budaya sekolah di SMP Negeri 15 Yogyakarta sebagai pelaksana program sekolah responsif gender dapat dilihat dari pembiasaan nilai-nilai, penyediaan fasilitas fisik dan non fisik sekolah; 2) Faktor pendukung sekolah dalam pelaksanaan budaya sekolah responsif gender di SMP Negeri 15 Yogyakarta adalah sudah adanya modal sarana dan prasarana yang cukup baik, dan dukungan dari warga sekolah, masyarakat serta pemerintah, sedangkan faktor penghambatnya adalah guru masih kesulitan dalam membuat model pembelajaran baru yang responsif gender, sekolah kesulitan dalam membuat kegiatan-kegiatan khusus responsif gender, pemahaman peserta didik masih kurang tentang kesetaraan gender walaupun sudah disosialisasikan, dan kasus bullying yang terjadi masih terjadi di sekolah.
\end{abstract}

Kata Kunci : Karakteristik Kultur Sekolah, Sekolah Responsif Gender

\begin{abstract}
The purposes of this study are to: 1) describe the characteristic of school culture in Junior High School of 15 Yogyakarta as the implementer of gender responsive school program; 2) describe the support and obstacle factors of school in the implementation of responsive gender school culture. This study uses qualitative approach with descriptive method. The subjects of this study are the head of school, the teachers, the students, and the parents of the student. The object of this study is the characteristic of the school culture in Junior High School of 15 Yogyakarta as the implementer of gender responsive program. The setting of this study is Junior High School of 15 Yogyakarta. The techniques to collect the data are observation, interview, and documentation. The technique to analyze the data uses Miles and Huberman's style analysis. Meanwhile, the technique of the validity uses triangulation of data source and triangulation of technique. The result of this study shows that:1) The characteristic of school culture in Junior High School of 15 Yogyakarta as the implementer of gender responsive program can be seen from the refraction of values, the provision of physics and non-physics of school facilities; 2) The support factors in the implementation of school culture of gender responsive in Junior High School of 15 Yogyakarta are from the good capital of infrastructure and the support from the members of school, society, and the government. Meanwhile, the obstacle factors are the teacher still feels difficult in order to make the new learning style which is gender responsive, the school feels difficult to make the activities especially in gender responsive, the understanding of the students about responsive gender are less even there is socialization, and bullying cases that happened in school
\end{abstract}

Keywords : Charateristics of School Culture, Gender Responsive School 


\section{PENDAHULUAN}

Pendidikan merupakan salah satu faktor terpenting dalam proses pembangunan di sebuah negara dan menjadi sebuah investasi jangka panjang yang dapat digunakan untuk membangun sektor sektor pembangunan seperti sektor ekonomi, sosial, budaya dan politik. Dalam proses pembangunan diperlukan pendidikan untuk mencetak generasi yang berkualitas, pendidikan diyakini sebagai faktor dominan dalam proses pembangunan negara, hal tersebut telah tertanam dengan dikeluarkannya Undang-Undang Nomor 20 tahun 2003 tentang Sistem Pendidikan Nasional.

Dalam Pasal 4 ayat (1) Undang-Undang Sistem Pendidikan Nasional Nomor 20 tahun 2003 menyatakan bahwa pendidikan dilaksanakan berdasarkan atas nilai - nilai demokratis dan berkeadilan serta tidak diskriminatif dengan menjunjung tinggi hak asasi manusia, nilai keagamaan, nilai kultural, dan kemajemukan bangsa. Selanjutnya, dalam Pasal 5 ayat (1) mempertegas bahwa setiap warga negara mempunyai hak yang sama untuk memperoleh pendidikan yang bermutu. Berdasarkan undang-undang tersebut dapat dipahami bersama bahwasanya setiap orang berhak dan memiliki kesempatan yang sama untuk mendapatkan pendidikan yang bermutu pada setiap jenjang pendidikan baik dalam pendidikan formal maupun nonformal tanpa harus membeda-bedakan jenis kelamin, agama, status sosial ekonomi, suku, ras dan golongan tertentu, dengan begitu konsep pendidikan yang berkeadilan dapat terwujud.

Pendidikan yang berkeadilan dimaknai sebagai pendidikan yang dapat mengakomodir hak - hak setiap orang akan pendidikan tanpa mendiskriminasi salah satu pihak. Dalam hal ini salah satu aspek yang perlu diperhatikan dalam mencapai pendidikan yang berkeadilan adalah kesetaraan gender. Pendidikan harus dapat memberikan akses atau kesempatan terhadap kesemuanya baik itu laki - laki maupun perempuan karena pendidikan merupakan hak bagi semua warga negara tanpa membeda-bedakan gender. Jadi, sudah seharusnya pendidikan dapat mengakomodir semua gender agar kesetaraan gender dapat terwujud.

Melihat pentingnya kesetaraan gender, pemerintah telah berupaya mengeluarkan beberapa kebijakan dalam mewujudkan kesetaraan gender. Melalui Inpres Nomor 9 tahun 2000 tentang Pengarusutamaan Gender dalam Pembangunan Nasional, yang kemudian ditindaklanjuti dengan dikeluarkannya Peraturan Menteri Dalam Negeri Nomor 15 Tahun 2008 tentang Pedoman Umum Pelaksanaan Pengarusutamaan Gender dalam Pembangunan di Daerah serta diikuti oleh Permendiknas Nomor 84 tahun 2008 tentang
Pedoman Pelaksanaan Pengarusutamaan Gender di Bidang Pendidikan.

Pengarusutamaan Gender dalam Bidang Pendidikan merupakan upaya yang strategis dalam mengenalkan, memahamkan, menyadarkan, mendorong, dan mewujudkan relasi gender yang berkeadilan dan berkesetaraan dalam situasi yang serasi dan harmonis guna mengurangi kesenjangan gender di berbagai aspek kehidupan, termasuk pendidikan yang nantinya dapat menjadi pendidikan yang responsif terhadap gender. Dengan adanya kebijakan kesetaraan gender dalam bidang bidang pendidikan seharusnya pendidikan yang diciptakan sudah ramah terhadap gender serta tidak bias gender.

Kenyataan yang terjadi di lapangan adalah masih ditemukannya bias gender dalam dunia pendidikan, bias gender ini berlangsung melalui proses serta sistem pembelajaran di sekolah. Contoh - contoh dari bias gender yang terjadi adalah ditemukannya bahan pembelajaran di sekolah yang bias terhadap gender seperti banyak gambar seorang pilot selalu laki-laki karena pekerjaan sebagai pilot memerlukan kecakapan dan kekuatan yang hanya dimiliki oleh laki-laki, sementara gambar guru yang sedang mengajar di kelas selalu perempuan karena guru selalu diidentikkan dengan tugas mengasuh atau mendidik. Selain itu ketika upacara bendera di sekolah bisa dipastikan bahwa pembawa bendera adalah siswa perempuan. Siswa perempuan itu dikawal oleh dua siswa laki-laki, hal tersebut tidak hanya terjadi di tingkatan sekolah namun sampai pada tingkat nasional (Efendy, 2014: 152-153).

Selain itu, ada kecenderungan pembelajaran yang bersifat stereotip, dimana anak laki-laki cenderung diberi motivasi untuk menjadi kuat, agresif, pemberani, dan didorong menjadi pemimpin, sedangkan perempuan cenderung diberi motivasi untuk menjadi penurut, tergantung, serta didorong untuk melakukan aktivitas kerumahtanggaan (domestik). Praktek ketidakadilan gender dalam bentuk pembakuan peran gender yang kaku terjadi karena adanya keyakinan dan pembenaran tentang peran gender yang kaku sehingga tertanam sepanjang hidup manusia yang akhirnya dianggap sebagai sesuatu yang wajar. Padahal, pembagian peran yang kaku dapat memberikan dampak kurang menguntungkan bagi peserta didik karena mereka tidak bisa tumbuh dan berkembang sebagai pribadi yang utuh dalam merespons dinamika kehidupan yang kompleks. Oleh sebab itu dalam rangka merubah semua bias gender, ketimpangan gender dan stereotip dalam kehidupan masyarakat, sangat diperlukan integrasi gender pada satuan pendidikan salah satunya adalah dengan menciptakan sekolah yang responsif gender. 
Sekolah responsif gender merupakan salah satu bentuk program dari implementasi kebijakan pengarusutamaan gender di bidang pendidikan, dalam kebijakan tersebut mengamanatkan bahwa seluruh proses dan program pembangunan pendidikan harus mengintegrasikan gender didalamnya, maka dari itu seharusnya program - program yang dibuat sekolah harus responsif terhadap gender. Namun, yang terjadi adalah masih rendahnya kesadaran pimpinan sekolah untuk mengintegrasikan gender ke dalam program sekolah. Tidak semua sekolah paham akan responsif gender, kemungkinan yang terjadi ketika sekolah tidak menerapkan program sekolah responsif gender berarti sekolah tersebut tidak sensitif terhadap Permendiknas No 84 tahun 2008 tentang Pedoman Pengarusutamaan Gender Bidang Pendidikan.

Program sekolah responsif gender bertujuan supaya lembaga pendidikan lebih menjamin persamaan peran dan tanggungjawab perempuan serta laki-laki secara adil dan setara dalam memperoleh akses pelayanan pendidikan, berpartisipasi aktif secara seimbang, memiliki kontol terhadap sumber - sumber pembangunan pendidikan dan menikmati manfaat dari hasil pembangunan pendidikan. Program sekolah responsif gender dikembangkan dengan mengoptimalkan terlayaninya kebutuhan peserta didik perempuan dan laki-laki secara seimbang. Dalam sekolah responsif gender semua pihak harus menyadari akan pentingnya keadilan dan kesetaraan gender, harapannya sekolah mampu melayani kebutuhan dan membukakan kesempatan seluas luasnya bagi perempuan maupun laki-laki untuk dapat berkembang.

Bentuk implementasi dari program sekolah responsif gender adalah melalui tiga proses yaitu, pertama melalui pembiasaan, pembiasaan ini dilakukan dalam bentuk pembagian kerja yang adil gender terhadap laki-laki dan perempuan. Cara kedua yaitu melalui intervensi, intervensi yang di maksud adalah perlakuan khusus oleh tenaga pendidik terhadap kebijakan sekolah. Bentuk intervensi dapat dilihat dari beberapa hal, di antaranya yaitu pembelajaran dan interaksi sehari-hari. Contoh bentuk intervensi dalam pembelajaran yaitu dengan penyebutan "peserta didik" dan pemberian motivasi nilai - nilai positif sebelum pembelajaran. Penyebutan peserta didik berawal dari asumsi sekolah bahwa jika menyebutkan kata siswa cenderung mengarah pada satu jenis kelamin yaitu laki-laki. Pemberian motivasi nilai - nilai positif diharapkan menumbuhkan semangat belajar peserta didik baik laki-laki maupun perempuan. Cara ketiga adalah melalui kegiatan kegiatan khusus (Faisal, 2018:568).

Aspek pembiasaan dalam implementasi sekolah responsif gender merupakan salah satu aspek penting karena aspek pembiasaan merupakan dasar dari sebuah budaya. Dalam lingkungan sekolah aspek tersebut biasa dinamakan dengan istilah kultur sekolah. Kultur sekolah dapat mempengaruhi cara berpikir, bersikap dan bertindak karena dilandasi oleh nilai nilai serta keyakinan. Selain itu, kultur sekolah dapat mendorong tumbuhnya perilaku positif, sehingga dapat digunakan untuk mendorong perilaku warga sekolah untuk lebih responsif terhadap gender.

Kultur sekolah merupakan nilai - nilai dan keyakinan yang ada di sekolah yang dipegang teguh secara bersama-sama oleh warga sekolah, kemudian digeneralisasikan ke antar generasi dan dapat dijadikan sebagai fondasi dalam menghadapi berbagai masalah yang ada di sekolah. Kultur sekolah sendiri memiliki peran penting dalam meningkatkan mutu pendidikan karena level analisis peningkatan mutu adalah sekolah, perubahan - perubahan yang terjadi baik dalam makna proses dan hasil harus terjadi di sekolah. Selain itu, kultur sekolah juga dapat dimanfaatkan untuk membuat kebijakan - kebijakan serta program - program yang nantinya akan menjadi ciri khas dari sekolah tersebut dan dapat membedakan sekolahnya dengan sekolah lain. Namun, yang terjadi adalah praktek kultur sekolah masih kurang diperhatikan karena ada beberapa nilai nilai yang terkadang tidak tercantum dalam bentuk artefak fisik seperti tulisan dan cenderung besifat abstrak, seperti nilai-nilai toleransi, disiplin, saling menghargai satu sama lain serta tidak membedabedakan golongan, ras, suku, jenis kelamin bahkan gender karena nilai nilai tersebut dapat dimaknai dan dibiasakan dalam keseharian.

Program sekolah responsif gender jika dihubungkan dengan kultur atau budaya sekolah dapat dikatakan bahwa kultur atau budaya sekolah merupakan aspek penting yang tidak dapat dipisahkan dalam lingkungan sekolah dan dapat mendukung pelaksanaan program sekolah responsif gender agar tercapai secara maksimal sehingga mutu sekolah dapat meningkat. Mengembangkan kultur atau budaya sekolah tidak akan berjalan dengan baik jika tidak didukung oleh seluruh warga sekolah itu sendiri. Setiap anggota sekolah baik itu kepala sekolah, guru, siswa, karyawan dan anggota sekolah lainnya memiliki peran penting dalam mengembangkan kultur sekolah dan dapat menginternalisasi nilai - nilai positif yang ada sekolah dalam mendukung program sekolah responsif gender, akan tetapi kurangnya sosialisasi dan kesadaran sekolah menjadi salah satu penghambat dalam mengembangkan kultur sekolah, sehingga peran kultur atau budaya sekolah dalam mendukung program - program yang dibuat sekolah tidak akan berjalan dengan baik.

SMP Negeri 15 Yogyakarta merupakan satusatunya sekolah di Kota Yogyakarta yang mengimplementasikan kebijakan Pengarusutamaan Gender di bidang pendidikan melalui program sekolah 
responsif gender. Sekolah tersebut membuat program tentang sekolah responsif gender yang menjadi ciri khas dan membedakannya dengan sekolah lain. Namun, program tersebut masih dalam tahap merintis, hal tersebut dikarenakan masih berjalan selama tiga tahun yaitu sejak tahun ajaran 2016/2017 tepatnya pada bulan Juni 2016 (Observasi, 16 September 2019). Pada tahap ini implementasi program sekolah responsif gender di SMP Negeri 15 Yogyakarta masih memerlukan penyesuaian agar mendapatkan hasil yang diinginkan, oleh sebab itu diperlukan pengembangan kultur sekolah dalam mendukung program sekolah responsif gender supaya hasil yang diinginkan segera tercapai secara maksimal, akan tetapi kenyataan yang terjadi adalah masih banyaknya sekolah yang belum menjadikan kultur sekolah sebagai fokus perhatian dalam meningkatkan kualitas sekolah, termasuk salah satunya dalam membudayakan responsif gender.

Melihat pentingnya kultur atau budaya sekolah dalam mendukung kebijakan atau program yang dibuat oleh sekolah, maka penulis tertarik untuk melakukan penelitian dengan judul "Karakteristik Budaya Sekolah di SMP Negeri 15 Yogyakarta sebagai Pelaksana Program Sekolah Responsif Gender".

\section{METODE PENELITIAN}

\section{Jenis Penelitian}

Penelitian ini menggunakan pendekatan kuallitatif deskriptif.

\section{Tempat dan Waktu Penelitian}

Penelitian ini dilaksanakan di SMP Negeri 15

Yogyakarta pada Oktober 2019 - Maret 2020.

\section{Subyek/Obyek Penelitian}

Subjek dalam penelitian ini adalah kepala sekolah, guru, peserta didik dan orang tua peserta didik. Objek dalam penelitian ini adalah karakteristik budaya sekolah di SMP Negeri 15 Yogyakarta sebagai pelaksana program sekolah responsif gender.

\section{Teknik Pengumpulan Data}

Teknik pengumpulan data yang digunakan adalah observasi, wawancara dan dokumentasi. Kegiatan observasi dalam penelitian ini adalah observasi partisipasi dimana penulis ikut terlibat dalam proses pendidikan di sekolah dengan tujuan untuk memperoleh data tentang artefak sekolah. Wawancara yang dilakukan dalam penelitian ini adalah wawancara secara mendalam (indept interview) dengan tujuan untuk mendapatkan data tentang budaya yang berkembang di SMP Negeri 15 Yogyakarta sebagai pelaksana program sekolah responsif gender, wawancara dilakukan dengan mewawancarai kepala sekolah, guru, dan beberapa peserta didik serta orangtua peserta didik. Dokumentasi dalam penelitian ini dilakukan dengan tujuan untuk memperkuat data yaitu melalui analisis data tentang dokumen yang ada seperti profil sekolah. Selain itu dokumentasi juga dilakukan dengan tujuan untuk mendapatkan data berupa gambar yang diambil melalui keadaan lingkungan sekolah seperti melihat benda - benda yang ada atau artefak fisik, interaksi guru dengan peserta didik, peserta didik dengan guru, kepala sekolah dengan peserta didik dan guru dan media untuk merekam saat wawancara berlangsung.

\section{Teknik Analisis Data}

Teknik analisis data dalam penelitian ini menggunakan model analisis data kualitatif dari Miles dan Huberma, Aktivitas analisisnya meliputi mengumpulkan data, kondensasi data, penyajian data, penarikan kesimpulan.

\section{Teknik Keabsahan Data}

Teknik keabsahan data dilakukan dengan cara triangulasi data sumber dan teknik. Triangulasi sumber dilakukan dengan menguji keterangan hasil wawancara dengan menggunakan hasil wawancara dari subyek yang lain, sedangkan triangulasi teknik dilakukan dengan menguji hasil wawancara dengan hasil observasi atau telaah dokumen.

\section{HASIL DAN PEMBAHASAN}

1. Karakteristik Budaya Sekolah Di SMP Negeri 15 Yogyakarta Sebagai Pelaksana Program Sekolah Responsif Gender

SMP Negeri 15 Yogyakarta telah melaksanakan program sekolah Responsif Gender berdasarkan atas dikeluarkannya Permendiknas No 84 tahun 2008 tentang Pedoman Pelaksanaan Pengarusutamaan Gender Bidang Pendidikan. Dalam permendiknas tersebut lembaga pendidikan diharapkan menjadi lebih responsif terhadap gender serta dapat menjamin persamaan hak antara perempuan dan laki-laki, diterapkannya program sekolah responsive tersebut menunjukkan bahwa SMP Negeri 15 Yogyakarta ikut serta dalam mendukung pemerintah dalam mengintegrasikan gender di dalam dunia pendidikan dan berperan dalam upaya percepatan program pengarustutamaan gender.

Selain itu latar belakang di selenggarakannya program sekolah responsif gender di SMP Negeri 15 Yogyakarta adalah karena sekolah perlu untuk meyeimbangkan peran serta kedudukan laki-laki dan perempuan dalam setiap kegiatan sekolah sehingga kedudukan partisipasi antara perempuan dan lakilaki adalah seimbang, dalam konsep sekolah responsif gender semua pihak meliputi tenaga pendidik, tenaga kependidikan, peserta didik, orangtua, tokoh dan anggota masyarakat disekitarnya, harus menyadari pentingnya keadilan dan kesetaraan gender (Kemendikbud, 2014:5). Hal tersebut, menegaskan bahwasanya warga sekolah 
perlu untuk menyadari pentingnya keadilan dan kesetaraan gender, dengan tujuan untuk menciptakan penyeimbangan peran serta kedudukan laki-laki dan perempuan, dimana kondisi laki-laki maupun perempuan dalam memperoleh hak-haknya adalah sama, seperti diberikannya peran perempuan untuk menjadi pemimpin upacara merupakan bentuk penyeimbangan peran serta pemenuhan hak yang sama untuk perempuan terhadap laki-laki.

Selanjutnya adalah kasus bullying yang dilakukan peserta didik laki-laki terhadap perempuan masih banyak terjadi, hal ini dikarenakan jumlah peserta didik di SMP Negeri 15 Yogyakarta yang cukup banyak hingga mencapai seribu orang, maka sekolah dapat dikatakan rawan terhadap kasus bullying sehingga faktor inilah yang juga menjadi alasan diselenggarakannya program sekolah responsif gender.

Potensi berprestasi yang dimiliki peserta didik laki-laki dan perempuan adalah sama, akan tetapi kesempatan yang dimiliki perempuan masih kurang, hal ini juga menjadi alasan yang melatarbelakangi penyelenggaraan program sekolah responsif gender, berprestasi yang dimaksud bukan hanya saja prestasi akademik akan tetapi juga ke peran sosial, sebagai contoh dalam peran sosial ialah peran menjadi pemimpin yang selama ini baik itu ketua osis, ketua kelas sampai pada pemimpin upacara biasanya di dominasi lakilaki akan tetapi dalam sekolah responsif gender perempuan juga diberikan hak kesempatannya untuk menjadi pemimpin.

Selanjutnya, faktor yang melatarbelakangi SMP Negeri 15 Yogyakarta menyelenggarakan program sekolah responsif gender adalah sarana dan prasarana yang dimiliki sudah mampu memfasilitasi kebutuhan peserta didik baik perempuan maupun laki-laki. Selain itu juga sekolah belum memiliki ciri khas yang dapat membedakannya dengan sekolah lain, maka dari itu SMP Negeri 15 Yogyakarta membuat program sekolah responsif gender yang nantinya dapat melabeli sekolah mereka serta menjadi ciri kekhususan sekolah.

Berdasarkan latar belakang di atas, SMP Negeri 15 Yogyakarta membuat program sekolah responsif gender ditandai dengan dikeluarkannya Surat Penugasan Nomor 188/459 tahun 2016 tentang Penugasan Guru dalam Tugas Tambahan Sebagai Panitia Kesetaraan Gender yang dibuat oleh Kepala Sekolah. Hal tersebut merupakan pembuktian dari bentuk keseriusan SMP Negeri 15 Yogyakarta dalam mewujudkan kesetaraan dan keadilan gender khususnya pada bidang pendidikan.

Budaya sekolah responsif gender di SMP Negeri 15 Yogyakarta dilaksanakan melalui bentuk pembiasaan nilai-nilai, penyediaan fasilitas fisik dan fasilitas non fisik. Pembiasaan nilai memiliki peran sebagai filter atas segala sesuatu yang masuk dari luar, kultur sekolah nantinya akan menyeleksi nilainilai apa yang perlu diterima dan dimasukan ke sekolah dan nilai-nilai apa yang perlu ditolak dan dijauhi agar nilai-nilai yang bersifat negatif tidak masuk ke dalam sekolah (Zamroni, 2016:92-93). SMP Negeri 15 Yogyakarta telah berusaha untuk menyeleksi nilai-nilai di sekolah yang tidak responsif gender salah satunya adalah dengan melakukan pemilihan bahan bacaan peserta didik yang tidak responsif terhadap gender. Hal ini dilakukan sebagai bentuk dari tindakan preventif agar bahan bacaan yang diterima oleh peserta didik tidak bias terhadap gender, artinya bahwa bahan bacaan di SMP Negeri 15 Yogyakarta sudah menyeimbangkan keberadaan laki-laki maupun perempuan baik itu dalam sektor publik maupun domestik. Hal tersebut penting untuk dilakukan karena, menurut Muawanah (2019:54) bias gender dapat dilihat dalam buku bacaan wajib di sekolah, yang sebagian besar mentransfer nilai atau norma gender yang berlaku dalam kebudayaan masyarakat. Artinya sistem nilai gender akan berpengaruh pada kehidupan sistem sosial di sekolah sebagai contoh adalah dalam buku ajar telah dikontruksi peran gender perempuan dan laki-laki secara segregasi, dimana laki-laki digambarkan sebagai pemiliki peran di sektor publik sedangkan perempuan digambarkan sebagai pemilik sektor domestik.

Nilai-nilai yang diterima atau perlu untuk ditanamkan di SMP Negeri 15 Yogyakarta dalam mendukung adanya kultur sekolah responsif gender adalah nilai kesetaraan, nilai kesetaaan merupakan kesamaan kondisi laki-laki maupun perempuan dalam memperoleh kesempatan dan juga haknya untuk berpartisipasi tanpa ada diskriminasi, dalam hal ini nilai kesetaraan gender bukan berarti mempertentangkan antara laki-laki dan perempuan, akan tetapi lebih dimaknai pada upaya membangun relasi dan kesempatan yang sama antara laki-laki dan perempuan (Efendy, 2014: 163), nilai-nilai kesetaraan di SMP Negeri 15 Yogyakarta dapat dilihat dari kesempatan yang dimiliki oleh perempuan untuk menjadi pemimpin adalah sama dengan lakilaki, hal ini juga berlaku pada kesempatan yang dimiliki oleh perempuan untuk menjadi pemimpin upacara. Selanjutnya yaitu akses kesempatan yang setara juga diberikan kepada perempuan untuk menduduki struktur kepemimpinan di organisasi OSIS dan juga kelas, dalam struktur kepemimpinan di SMP Negeri 15 Yogyakarta peran perempuan sudah menduduki pada level ketua.

Selain itu, nilai keadilan juga ditanamkan oleh SMP Negeri 15 Yogyakarta dengan tujuan untuk 
tidak membeda-bedakan peserta didik serta menempatkan perlakuan antara laki-laki dan perempuan sesuai dengan kebutuhannya. Dalam menciptakan nilai keadilan gender, menurut Muawanah (2009:33) diperlukan pemenuhan atas kepentingan praktis gender dan kepentingan strategis gender. Kepentingan/ keperluan praktis gender merupakan keperluan yang diidentifikasi untuk membantu perempuan yang masih di bawah (subordinasi) dalam masyarakat sekarang. Konsep ini tidak menentang pembagian secara seksual atau posisi subordinasi perempuan dihadapan laki-laki, akan tetapi lebih pada penekanan kebutuhan langsung yang dibutuhkan oleh laki-laki maupun perempuan. Di SMP Negeri 15 Yogyakarta ditemukan bentuk implementasi praktis gender yaitu dengan adanya ruang laktasi yang dibuat dengan tujuan untuk memenuhi kebutuhan spesifik perempuan terutama yang sedang dalam masa menyusui. Selain itu juga dapat dilihat dari bentuk perlakuan sekolah terhadap jumlah kamar mandi perempuan yang lebih banyak dibandingkan lakilaki, hal tersebut diberlakukan karena faktor kebutuhan perempuan yang cenderung lebih lama dibanding laki-laki.

SMP Negeri 15 Yogyakarta telah berkomitmen dalam membangun kultur responsif gender melalui program sekolah resposif gender, hal ini dapat dilihat dari pembiasaan nilai melalui penyediaan fasilitas fisik sekolah seperti tersedianya fasilitas sarana dan prasarana dalam rangka mendukung adanya program sekolah responsif gender. Sarana dan prasarana dalam sekolah responsif gender tersebut diharapkan dapat mengakomodir kebutuhan peserta didik tanpa ada diskriminasi, SMP Negeri 15 Yogyakarta memiliki fasilitas sarana dan prasarana yang cukup baik sebagai penunjang progam sekolah responsif gender, hal tersebut penting karena salah satu indikator standar dalam sekolah responsif gender ialah sarana dan prasarana (Kemendikbud, 2014:10-21). Adapun fasilitas sarana dan prasarana tersebut antara lain adalah ruang laktasi yang dikhususkan untuk ibuibu yang sedang menyusui. Ruangan ini terletak di dalam ruang kantor guru tepatnya di sudut paling belakang. Ruang laktasi ini berguna untuk memberikan kenyamanan perempuan yang masih menyusui. Ruang laktasi menjadi sangat penting dalam sekolah responsif gender, karena salah satu tujuan dari sekolah responsif gender adalah menjamin kebutuhan spesifik baik itu laki-laki maupun perempuan terlayani dengan baik termasuk dalam hal ini kebutuhan perempuan. Ruang laktasi ini bisa digunakan oleh guru perempuan maupun tamu sekolah perempuan yang sedang menyusui.
Sarana dan prasarana selanjutnya yaitu jumlah kamar mandi yang dimiliki SMP Negeri 15 Yogyakarta sudah cukup untuk mengakomodir kebutuhan dengan jumah sebanyak dua puluh enam ruangan. Kamar mandi tersebut dibagi menjadi dua yaitu kamar mandi untuk laki-laki sebanyak dua belas ruang sedangkan untuk kamar mandi perempuan sebanyak empat belas ruang. Sistem pembagian jumlah kamar mandi perempuan yang lebih banyak dibandingkan laki-laki disebabkan karena faktor kebutuhan, dimana perempuan lebih membutuhkan dan cenderung lebih lama di dalam kamar mandi dibandingkan laki-laki. Selain itu, sistem kamar mandi di SMP Negeri 15 Yogyakarta yang sudah terpisah juga dapat memberikan rasa nyaman dan aman peserta didik serta dapat mencegah terjadinya pelecehan seksual kepada peserta didik.

Kemudian, fasilitas sarana dan prasarana Unit Kesehatan Sekolah (UKS). UKS merupakan sarana yang penting dan harus dimiliki oleh setiap sekolah, hal ini disebabkan karena sebagai bentuk penangganan ketika terjadinya kecelakaankecelakaan kecil di sekolah. SMP Negeri 15 Yogyakarta memiliki dua ruang UKS yaitu ruang UKS untuk laki-laki dan ruang UKS untuk perempuan. Tujuan dari pemisahan tersebut antara lain adalah sebagai bentuk tindakan preventif sekolah dalam mengatasi kejadian-kejadian yang tidak diinginkan, selain itu juga perbedaan kebutuhan yang dimiliki laki-laki dan perempuan serta adanya privasi yang dimiliki keduanya seperti dalam hal ketika perempuan sedang datang bulan. Dampak yang dirasakan dengan adanya ruang UKS terpisah antara laki-laki dan perempuan adalah pada kenyamanan akses terhadap kebutuhan laki-laki dan perempuan. Hal ini dapat dimaknai bahwasanya kesetaraan gender tidak berarti menyamaratakan semua kebutuhan antara laki-laki dan juga perempuan, akan tetapi tetap harus menghormati batas-batas tertentu antara laki-laki dan perempuan.

Selain itu terdapat fasilitas ruang ganti peserta didik, tersedianya ruang ganti yang terpisah di antara laki-laki dan perempuan merupakan salah satu keharusan yang dimiliki sekolah untuk menciptakan kultur responsif gender karena dengan adanya fasilitas tersebut dapat menciptakan rasa aman serta nyaman pada peserta didik dan dapat mencegah terjadinya hal-hal negatif yang tidak diinginkan baik pada perempuan maupun laki-laki.

Sarana dan prasarana selanjutnya adalah ruang bimbingan dan konseling yang terletak di samping ruang UKS. Tersedianya ruangan tersebut dapat memenuhi kebutuhan konsultasi peserta didik dan dapat menjamin kenyamanan peserta didik dalam menyampaikan persoalan pribadi baik itu laki-laki maupun perempuan. Ruang bimbingan dan konseling 
di SMP Negeri 15 Yogyakarta bersifat tertutup dan aman sehingga peserta didik laki-laki maupun perempuan dapat secara terbuka menyampaikan persoalan pribadinya tanpa ada rasa tertekan.

SMP Negeri 15 Yogyakarta juga memiliki ruang keterampilan sebagai sarana dan prasarana penunjang program sekolah responsif gender, ruang keterampilan ini terletak di sebelah selatan sekolah, ruangan ini memiliki ciri khas dari bangunan peninggalan Hindia Belanda yang cenderung tinggi dan besar. Ruang keterampilan ini masih digunakan sebagai tempat pembelajaran peserta didik khususnya pada pembelajaran keterampilan. Melalui ruang keterampilan ini dapat dimaknai bahwa sekolah sudah berupaya dalam menyediakan fasilitas untuk peserta didik baik laki-laki maupun perempuan untuk membuat karya kerajinan. Nilai kesetaraan gender dalam hal ini adalah peserta didik laki-laki dan perempuan memiliki akses atau kesempatan yang sama dalam mengembangkan bakat serta minatnya dalam seni kerajinan dan sekolah memfasilitasi hal tersebut.

Sarana dan prasarana terakhir adalah aula serba guna yang merupakan salah satu penunjang proses pembelajaran di sekolah. Aula SMP Negeri 15 Yogyakarta biasanya berfungsi sebagai kegiatan olahraga indoor, selain itu aula ini juga merupakan sarana penunjang program sekolah responsif gender karena digunakan untuk memberikan sosialisasi ataupun workshop tentang kesetaraan gender dan juga kajian keputrian yang dilaksanakan di aula serba guna.

Karakteristik lainnya yang terlihat pada sekolah yang menerapkan kultur responsif gender adalah adanya penyediaan fasilitas fisik berupa sloganslogan yang menggambarkan bentuk sosialisasi kultur responsif gender dengan tujuan untuk memotivasi antar warga sekolah supaya dapat meningkatkan kultur positif yang responsif gender. Adanya dukungan dari segi artefak fisik dapat memperkuat kultur responsif gender yang akan dibangun oleh sekolah dan bisa mempengaruhi warga sekolah untuk berperilaku responsif terhadap gender karena menurut Zamroni, (2016:94) kultur sekolah juga memiliki peran dalam mempengaruhi warga sekolah tentang bagaimana harus berpikir, bersikap dan bertindak (Zamroni, 2016:94).

Berkaitan dengan visi dan misi, SMP Negeri 15 Yogyakarta memiliki tujuan untuk melakukan perubahan sekolah menjadi lebih baik salah satunya dengan menciptakan kultur yang responsif gender, oleh karena itu perubahan yang dilakukan seharusnya berjalan sesuai dengan perubahan visi dan misi sekolah, karena menurut Zamroni (2007:22) kultur sekolah yang mengalami perubahan yang lebih baik adalah kultur sekolah yang didukung oleh visi sekolah. Visi dan misi yang dibuat oleh SMP Negeri 15 Yogyakarta sudah menggambarkan konsep gender didalamnya, sehingga dapat mempermudah sekolah dalam menerapkan kultur responsif gender, hal ini disebabkan karena pedoman tentang bagaimana cara sekolah bertindak serta membuat program-program haruslah sejalan dengan visi dan misi sekolah. Bentuk aktualisasinya di SMP Negeri 15 Yogyakarta adalah dengan memasukan unsur responsif gender ke dalam visi dan misi sekolah, selain itu faktor asumsi juga memiliki peran penting dalam pelaksanaan program yang dibuat sekolah, salah satunya adalah program sekolah responsif gender.

Selanjutnya pembiasaan nilai-nilai budaya responsif gender dapat dilihat dari penyediaan fasilitas non fisik, dalam hal ini fasilitas non fisik yang dimaksudkan adalah artefak sekolah yang mudah diamati seperti dalam hal kebiasaan-kebiasaan serta interaksi yang dilakukan warga sekolah dalam mendukung terlaksananya program sekolah responsif gender. Kultur sekolah memiliki peran yang sangat penting dalam kehidupan sekolah untuk mewujudkan tingkat kualitas sekolah yang lebih tinggi (Zamroni, 2016:91). Oleh karena itu, peranan kultur sekolah dapat dimanfaatkan untuk meningkatkan kehidupan sekolah jika dikaji secara sungguh-sungguh termasuk dalam hal penyediaan fasilitas non fisik seperti bagaimana interaksi yang terjadi diantara guru, bagaimana kebersamaan yang terjalin diantara mereka, hal tersebut merupakan faktor yang penting dalam kehidupan sekolah yang terjabarkan dalam berbagai aktivitas dan juga kebiasaan-kebiasaan.

SMP Negeri 15 Yogyakarta memiliki kebiasaankebiasaan yang berperan dalam mendukung program sekolah responsif gender. Bentuk pembiasaan ini dilakukan dengan bentuk pembagian kerja yang adil gender terhadap laki-laki dan perempuan. Nugroho (2008:29) menyampaikan bahwa keadilan gender adalah sebuat proses untuk memperlakukan secara adil terhadap laki-laki dan perempuan, hal tersebut dapat dimaknai bahwa tidak ada lagi pembakuan peran, beban ganda, subordinasi, marginalisasi dan kekerasan terhadap jenis kelamin tertentu. Bentuk pembagian yang adil gender di SMP Negeri 15 Yogyakarta adalah pada pembagian tugas saat upacara bendera di hari senin. Petugas upacara tidak selalu didominasi oleh satu jenis kelamin, laki-laki dan perempuan mendapat kesempatan yang sama untuk berperan dalam kegiatan upacara. Hal ini dilakukan dengan tujuan untuk memberikan pembelajaran dan pembiasaan kepada setiap peserta didik untuk berperan aktif dalam kegiatan sekolah.

Selain itu bentuk pembiasaan yang dilakukan adalah melalui budaya kepemimpinan yang responsif gender, dalam hal ini budaya kepemimpinan yang 
dibangun tidak hanya mengutamakan atau mengunggulkan laki-laki tetapi juga memberikan hak yang sama kepada perempuan asalkan memiliki kemampuan. Menurut Remiswal (2013:27) bahwa pendidikan gender adalah upaya yang dilakukan secara sadar oleh anggota sekolah dalam menempatkan hak-hak sipil laki-laki dan perempuan sebagai makhluk individu dan sosial yang setara dan adil untuk mengaktualisasikan diri dalam kegiatan pembangunan. Bentuk pemberian hak yang sama terhadap laki-laki dan perempuan di SMP Negeri 15 Yogyakarta adalah dalam hal menjadi ketua organisasi OSIS, ketua kelas, maupun pemimpin upacara.

Pengintegrasian kultur responsif gender dalam pembelajaran merupakan suatu hal yang perlu diperhatikan, hal tersebut dikarena dalam proses pembelajaran memiliki pengaruh penting terhadap siswa dan juga guru, oleh karena itu jika sekolah ingin menciptakan kultur responsif gender yang positif maka sekolah harus memperhatikan pembelajarannya juga, karena menurut Gary Phillips conculting Center or improving school culture dalam Zamroni (2016:92) mengatakan bahwa pembelajaran yang positif hanya dapat berlangsung pada sekolah yang memiliki kulltur posititif pula dan kultur sekolah sehat akan mempengaruhi siswa dan juga guru. Oleh karena itu melihat pentingnya pembelajaran dalam mempengaruhi dan menciptakan kultur responsif gender, SMP Negeri 15 Yogyakarta mengaktualisasikannya dengan melakukan pembiasaan yaitu memberikan pesan-pesan moral pada awal pembelajaran termasuk pesan-pesan kesetaraan dan keadilan gender.

Kurikulum sekolah responsif gender di SMP Negeri 15 Yogyakarta hampir sama dengan kurikulum sekolah lain pada umumnya, dalam hal ini pendidikan sekolah responsif gender akan lebih fokus dalam memberikan penguatan terhadap MBS dengan memasukan pertimbangan gender dalam setiap komponen MBS (Kemendiknas, 2010:9) bentuk pertimbangan gender dalam setiap komponan manajemen sekolah di SMP Negeri 15 Yogyakarta adalah dalam hal administrasi sekolah termasuk kurikulum penyebutannya sudah menggunakan istilah peserta didik bukan menggunakan istilah siswa, karena istilah siswa cenderung menunjukkan kepada peserta didik lakilaki saja.

Selain kurikulum, penerapan model pembelajaran oleh guru dalam sekolah responsif gender merupakan salah satu hal yang penting dalam mencapai kultur responsif gender karena menurut Muawanah (2019:57) apabila guru memiliki sensitivitas gender maka akan memiliki itikad untuk menciptakan keadilan dan kesetaraaan gender dengan sendirinya, melalui proses pembelajaran di kelas, dalam pembuatan soal dan dalam perlakuan di kelas. Dalam hal ini guru memiliki peran penting dalam melakukan proses sosialisasi kultur gender di dalam pembelajaran seperti dalam bentuk perlakuan di kelas.

Bentuk perlakuan responsif gender guru dalam model pembelajaran di SMP Negeri 15 Yogyakarta adalah pada setiap pembentukan kelompok diskusi harus diupayakan terdiri dari laki-laki dan perempuan, guru juga sudah memberikan kesempatan yang sama antara peserta didik laki-laki dan perempuan untuk aktif dalam menyampaikan pendapat, dalam pembelajaran peserta didik laki-laki maupun perempuan juga aktif dalam mengemukakan gagasan serta bertanya tanpa merasa minder atau lebih hebat (superior). Serta guru juga sudah berinisiatif memasukan ice breaking di setiap pembelajaran dengan tujuan supaya pembelajaran dapat berjalan dengan lebih menyenangkan. Selain itu, dilihat dari prestasi sekolah di SMP Negeri 15 Yogyakarta sebagai pelaksana program sekolah responsif gender, ditemukan bahwa prestasi di sekolah tersebut sudah menunjukkan keadilan tanpa mendiskriminasi salah satu gender, seperti kesempatan peserta didik untuk mengikuti kegiatan perlombaan dan pada peran sosial di sekolah.

Adanya pembiasaan nilai-nilai responsif gender yang didukung dengan adanya penyediaan fasilitas fisik dan fasilitas non fisik, maka hal tersebut berdampak pada berkembangnya asumsi positif di sekolah. Asumsi merupakan pandangan warga sekolah terhadap sekolah mereka, jika sekolah sudah memiliki pandangan serta keyakinan tentang program yang dilaksanakan sekolah, maka hal tersebut akan mempermudah sekolah dalam mengimplementasikan program tersebut, warga sekolah di SMP Negeri 15 Yogyakarta sudah merasa percaya bahwa sekolah ramah terhadap perempuan dan adil terhadap gender, warga sekolah memiliki rasa bangga terhadap sekolah, dan juga warga sekolah sudah menunjukkan sikap optimisnya melalui bentuk mendukung dan merasa senang terhadap program sekolah responsif gender. Oleh karena itu asumsi yang terbangun di SMP Negeri 15 Yogyakarta merupakan asumsi positif yang berperan untuk mendukung adanya budaya sekolah responsif gender.

\section{Faktor Pendukung dan Penghambat Sekolah dalam Pelaksanaan Budaya Sekolah Responsif Gender}

Sekolah responsif gender merupakan sekolah yang baik secara aspek akademik, lingkungan fisik maupaun masyarakatnya sudah memperhatikan secara seimbang kebutuhan spesifik untuk anak lakilaki dan perempuan (Wibowo, 2010:193). Hal 
tersebut dapat dimaknai bahwasanya dalam menerapkan program sekolah responsif gender diperlukan suatu perencanaan yang baik agar kebutuhan spesifik peserta didik dapat terpenuhi secara seimbang dan oleh sebab itu penerapan suatu program akan berjalan dengan baik jika memiliki faktor pendukungnya. SMP Negeri 15 Yogyakarta dalam melaksanakan program sekolah resposif gender memiliki faktor pendukung diantaranya adalah sudah adanya modal sarana dan prasarana yang cukup baik dan dukungan dari warga sekolah, masyarakat serta pemerintah.

SMP Negeri 15 Yogyakarta sudah memiliki sarana dan prasana yang cukup baik yang sebelumnya dapat mendukung adanya budaya sekolah responsif gender seperti kamar mandi terpisah antara laki-laki dan perempuan, ruang bimbingan dan konseling, UKS dan ruang ganti terpisah antara laki-laki dan perempuan, ruang keterampilan, dan aula serba guna.

Selain itu, faktor dukungan dari warga sekolah dan masyarakat juga menjadi kekuatan sekolah dalam menerapkan kultur responsif gender, di SMP Negeri 15 Yogyakarta seluruh warga sekolah sudah saling bekerjasama dalam mendukung program responsif gender, dan guru-guru di SMP Negeri 15 Yogyakarta juga sudah mengikuti workshop sekolah responsif gender yang diselenggarakan oleh sekolah, serta orangtua peserta didik dan juga peserta didik juga sudah diberikan sosialisasi terkait program sekolah responsif gender. Selanjutnya, adanya faktor dukungan dari pemerintah yang secara tidak langung dapat memberikan dukungan untuk terselenggaranya program sekolah responsif gender, hal tersebut berupa alokasi dana dari pemerintah yang diberikan untuk perbaikan fasilitas sarana dan prasarana sekolah.

Dalam menerapkan program sekolah responsif gender tidak mungkin dapat berjalan secara sempurna, artinya bahwa masih ada berbagai faktor yang menjadi penghambat berjalannya program sekolah responsif gender di SMP Negeri 15 Yogyakarta. Dari data penelitian melalui wawancara, observasi dan dokumentasi dapat diketahui berbagai hambatan yang muncul dalam pelaksanaan program sekolah responsif gender di SMP Negeri 15 Yogyakarta antara lain adalah pertama, guru masih kesulitan dalam membuat model pembelajaran baru yang responsif gender sehingga model pembelajaran yang berjalan masih bersifat monoton. Faktor kedua adalah sekolah kesulitan dalam membuat kegiatan-kegiatan khusus responsif gender sehingga kegiatan program sekolah responsif gender kebanyakan bersifat dadakan atau insidental dan kurang bervariatif. Faktor ketiga adalah pemahaman peserta didik masih kurang tentang kesetaraan gender walaupun sudah disosialisasikan, sehingga yang berkembang malah justru pemahaman gender yang negatif. Faktor terakhir adalah masih terjadinya kasus bullying di sekolah, hal ini disebabkan karena penanaman nilai-nilai responsif gender kepada peserta didik laki-laki akan kesetaraan masih sulit, banyak peserta didik laki-laki masih merasa unggul dan meremehkan peserta didik perempuan.

\section{SIMPULAN DAN SARAN \\ Simpulan}

Karakteristik budaya sekolah di SMP Negeri 15 Yogyakarta sebagai pelaksana program sekolah responsif gender di SMP Negeri 15 Yogyakarta dapat dilihat dari pembiasaan nilai-nilai, penyediaan fasilitas fisik dan fasilitas non fisik. Pembiasaan nilainilai yang ditanamkan adalah nilai kesetaraan dan nilai keadilan. Penanaman nilai-nilai tersebut didukung melalui bentuk penyediaan fasilitas fisik seperti sarana dan prasarana, slogan atau poster serta visi dan misi. Selain itu juga didukung dengan adanya fasilitas non fisik seperti pembiasaan sekolah yaitu pembagian kerja yang adil gender, budaya kepemimpinan yang responsif gender serta pembelajaran yang responsif terhadap gender. Dengan adanya pembiasaan nilai, penyediaan fasilitas fisik dan fasilitas non fisik maka dapat menumbuhkan asumsi positif, asumsi yang ditemukan adalah warga sekolah percaya dan yakin bahwa sekolah sudah ramah terhadap perempuan dan adil terhadap gender.

Faktor pendukung sekolah dalam pelaksanaan budaya sekolah responsif gender di SMP Negeri 15 Yogyakarta adalah sudah adanya modal sarana dan prasarana yang cukup baik dan dukungan dari warga sekolah, masyarakat serta pemerintah. Sedangkan faktor penghambat sekolah dalam pelaksanaan budaya sekolah responsif gender di SMP Negeri 15 Yogyakarta adalah guru masih kesulitan dalam membuat model pembelajaran baru yang responsif gender, sekolah kesulitan dalam membuat kegiatankegiatan khusus responsif gender, pemahaman peserta didik masih kurang tentang kesetaraan gender walaupun sudah disosialisasikan, dan kasus bullying yang terjadi masih terjadi di sekolah.

\section{Saran}

\section{Bagi Dinas Pendidikan}

Menjadikan SMP Negeri 15 Yogyakarta sebagai model sekolah yang memiliki kultur positif yang responsif gender sehingga sekolah lain yang belum memiliki kultur responsif gender dapat menerapkan program sekolah responsif gender serupa melalui penyesuaian dengan potensi yang dimiliki oleh sekolah untuk membentuk kultur positif yang responsif gender di sekolah mereka masing-masing. 
2. Bagi SMP Negeri 15 Yogyakarta Diharapkan SMP Negeri 15 Yogyakarta dapat mempertahankan kultur positif responsif gender yang telah dipelihara selama ini sehingga kultur yang telah tertanam tidak pudar.

3. Bagi Sekolah Lain

Saran bagi sekolah lain yaitu sebaiknya sekolah-sekolah lain dapat mengikuti dan menerapkan kultur positif yang responsif gender dari SMP Negeri 15 Yogyakarta.

4. Bagi Peneliti Lebih Lanjut

Saran bagi peneliti selanjutnya adalah dengan melakukan penelitian mengenai evaluasi program sekolah responsif gender di SMP Negeri 15 Yogyakarta.

\section{DAFTAR PUSTAKA}

Depdikbud. (2003). Undang-Undang RI Nomor 20 Tahun 2003 tentang Sistem Pendidikan Nasional.

Dewi R.K. (2016). Studi Analisis Kebijakan. Bandung: CV Pustaka Setia.

Efendy, Rustan (2014). Kesetaraan Gender Dalam Pendidikan. Jurnal Al-Maiyyah, Vol 07 No. 2 .

Faisal.D.W.N (2018). Implementasi Program Sekolah Responsif Gender di SMP Negeri 15 Yogyakarta. Skripsi Program Studi Pendidikan Ilmu Pengetahuan Sosial Fakultas Ilmu Sosial Universitas Negeri Yogyakarta.

Fakih, M. (2013). Analisis gender dan Transformasi Sosial.Yogyakarta: Pustaka Pelajar.

Handayani, Trisakti dan Sugiarti. (2008). Konsep dan Teknik Penelitian Gender Edisi Revisi. Malang: UMM Press.

Hanum, Farida, dkk. (2017). Sosiologi dan Antropologi Pendidikan. Yogyakarta: UNY Press.

Hasbullah, H.M. (2016) Kebijakan Pendidikan Dalam Perspektif Teori, Aplikasi, dan Kondisi Objektif Pendidikan di Indonesia. Jakarta: PT Raja Grafindo Persada.

Kemendikbud. (2014). Pengarusutamaan Gender Buku 5: Indikator Sekolah Responsif Gender. Jakarta: Kemendikbud.

Kemendiknas. (2010). Panduan Pelaksanaan Pendidikan Berwawasan Gender Untuk SMP. Jakarta: Kemendiknas.

Maunah, Binti. (2009). Ilmu Pendidikan. Yogyakarta: Teras.

Moleong, Lexy J (2010). Metodologi Penelitian Kualitatif. Bandung: PT Remaja Rosdakarya.
Moleong. Lexy J (2017). Metodologi Penelitian Kualitatif. Bandung: PT Remaja Rosdakarya.(Edisi Revisi).

Muawanah, Elfi. (2009). Pendidikan Genderr dan Hak Asasi Manusia. Yogyakarta: Teras.

Oktaviani, Via. (2017). Sosialisasi Perbedaan dan Peran Gender Terhadap Siswa/Siswi Madrasah Ibtidaiyah Mathlaul Anwar Nagrog Ciampe Bogor. Skripsi Jurusan Pendidikan Ilmu Pengetahuan Sosial, Fakultas Ilmu Tarbiyah dan Ilmu Keguruan, UIN Syarif Hidayatullah, Jakarta.

Prastowo, Andi (2012). Metode Penelitia Kualitatif dalam Perspektif Rancangan Penelitian. Yogyakarta: Ar-Ruzz Media.

Riska, Wahyu R. (2014). Perananan Kultur Sekolah dalam Mendukung Pelaksanaan Kurikulum 2013 di SMA Negeri 1 Sedayu Bantul pada Tahun Ajaran 2013/2014. Tesis magister, tidak diterbitkan, Universitas Negeri Yogyakarta, Yogyakarta.

Rohman, Arif (2012). Kebijakan Pendidikan: Analisis Dinamika Formulasi dan Implementasi. Yogyakarta: Aswaja Pressindo.

Sugiyono. (2016). Memahami Penelitian Kualitatif. Bandung: Alfabeta

Suharno. (2016). Dasar-dasar Kebijakan Publik: Kajian Proses dan Analisis Kebijakan. Yogyakarta: Penerbit Ombak.

Sukmadinata, Nana Syaodih (2009). Metode Penelitian Pendidikan. Bandung: PT Remaja Rosdakarya.

Suryadi, A. (2010). Kesetaraan Gender dalam Bidang Pendidikan. Bandung: PT. Genesido.

Wibowo, Dwi Edi. (2010). Sekolah Berwawasan Gender. Jurnal Muwazah, Vol 2, No 1.

Zamroni. (2016). Kultur Sekolah.Yogyakarta: Gavin Kalam Utama. 